American Research Journal of English and Literature

ISSN (Online): 2378-9026

Volume 5, Issue 1, 2019, 1-6 Pages

DOI: 10.21694/2378-9026.19001

AMERICAN RESEARCH JOURNALS

An Academic Publishing House

\title{
Appropriating Emotional Distress, Disturbance, and Grief in the Novel Heart of Darkness and the Film Apocalypse Now - A Brief Analysis
}

\author{
Dr. Craig Doughty \\ Department of History, Keele University, United Kingdom. \\ drcdoughty@outlook.com
}

\begin{abstract}
This article presents an analytical insight into the characters of Marlowe in Joseph Conrad's novella, 'Heart of Darkness' and Francis Ford Coppola's appropriation of that character, Willard in the film, 'Apocalypse Now'. Both characters are used to document and deal with concepts of colonialism and the impact of foreign interference in lands deemed harsh and unforgiving: the Congo and Mekong respectively. In doing so, Marlowe and Willard make relentless journeys during periods of heightened historical conflict that lead both characters down spirals of emotional suffering. Interwoven into the fabric of these journeys are the distresses and pains of their creators. As such, Marlowe and Willard act as vessels for autobiographical forays.Principally, however, Conrad and Coppola use Marlowe and Willard as reference points for concepts of human morality. They compel the reader and the viewer, respectively, to question to what extent common morality is shared by most or all human beings and furthermore, is accessible to, and binding upon, all rational beings.
\end{abstract}

\section{INTRODUCTION}

Joseph Conrad's Heart of Darkness and Francis Ford Coppola's appropriation Apocalypse Now are works that purposefully deal with the notion of introspective journeysthat lead to spiritual change. Such change, which can loosely be described as a conscious awakening to the wide-ranging horrors of mankind, occurs within intricately woven mosaics of physical and psychological suffering. In this respect, using colonialism as their nucleuses, both works present multi-layered observations on the struggle to maintain human morality when morality no longer bears guaranteed validity. As protagonists Charles Marlow (Heart of Darkness) and Willard (Apocalypse Now) embark on expeditions that physically and mentally lead to places they never intended to reach, the public issue of colonialism becomes decisively interwoven with the private issue of self-discovery. The two are presented as indissoluble.

\section{Appropriating Emotional Distress, Disturbance, And Grief in the Novel Heart of DARKNESS AND THE FILM APOCALYPSE NOW}

Out of the folly, madness, and horror of collective enterprise - war and colonisation - emerges an existentialist realisation that the world men make for themselves principally stems from the character of individual behaviour: 'We live, as we dream-alone' (Conrad, 11). But insofar as Marlow and Willard are to certain extents men of reputation and sincerity, they are nonetheless fallible human beings. Despite their superior status on their respective boats, Marlow and Willard possess a normal capacity for good and evil and the liability to make the same errors as those they denounce in others. Ultimately, that is the intention of their creators. Conrad and Coppola present human beings as they are not as they ought to be. They dictate that each situation demands an individual choice and not a blind adherence to a code: Willard's decision not to call in the air strike following his murder of Kurtz is a suitable example.

While Marlow is presented as a fictional English seaman, his character is a narrative channel repeatedly utilised by Conrad for the purposes of manifesting his contemplative forays into self. Marlow appears in several of 
Appropriating Emotional Distress, Disturbance, and Grief in the Novel Heart of Darkness and the Film Apocalypse Now - A Brief Analysis

Conrad's works, beginning with his 1898 autobiographical short story Youth (2016). In the Author's Notes to Heart of Darkness: SecondEdition, while discussing Youth Conrad remarks of Marlow that 'He haunts my hours ofsolitude, when, in silence, we lay our heads together in great comfort and harmony' (1998). Marlow serves as Conrad's muse, his mouthpiece, and on occasion a veil behind which to hide; i.e., Marlow is a personification of the author's inner voice-while also providing a freedom of presence in his works.

Conrad's Congo is as such both the historically located site of an imperialist atrocity and a personally-laden psychic phantasmagoria. In this context the story is less about the relationship between Marlow and Kurtz and more about the overarching dichotomy that exists between protagonist and author. While Marlow's Englishness marks him off from his Polish-born creator, Heart of Darkness is littered with autobiographical links. Eightand-a-half years before it was completed, Conrad served as the captain of a Congo steamer, the Roi des Belges (Najder, 159). Allan Simmons' biography also connects Conrad and Marlowthrough near identical experiences aboard the ill-fated Palestine, a ship which sank off the coast of Sumatra in March of 1883 (Simmons, 81).

It is the mental connection between Marlow and Conrad however that prompts the most intrigue. Marlow is, in the main, an introspective character. He is described in Heart of Darkness as a 'Traveller in the country of the mind' (1989).On the surface, he is always observingand judging, but there is an underlying sense that his perceptions serve as juxtaposition for his own inner conflicts-in essence, uneasy apprehensions of colonialism. Gene M. Moor's assertion that we, the reader, 'are in Marlow's mind throughout' the narrative is reified by Albert J. Guerard's claim that the story is about Marlow's 'night journey into the unconscious, and confrontation of an entity within the self' (In Tredell, 87). For insofar as 'going into the jungle seems to Marlow like travelling into one's own mind', it is ultimately a reflective journey that Conrad takes vicariously through his protagonist—a journey that develops an ambivalent attitude towards colonialism by its end.

The notion of introspection is similarly true of 'Apocalypse Now'. Eleanor Coppola, in her Notes on the Making of the film details the strains and challenges experienced by her husband, and director, Francis Ford Coppola (1995). She comments that Coppola's arduous journey towards the film's completion, which had by 1979 spanned some nine years, slowly started to mirror the journey up the Nung river made by its protagonist, Willard. In the same respect that Willard is gripped by a 'fear of failure, fear of death, (and a) fear of going insane', Coppola's journey is by his own admission comparable; Eleanor notes that there was a point during the 18 months of filming when reality and fiction became entwined:

I was watching from the point of view of the observer, not realising that I was on the journey too. Now I can't go back to the way it was. Neither can Francis. Neither can Willard (1995).

Successfully, novel and film incorporate various dualisms to address the subject of human nature. The themes of method and madness appear consistently throughout. Moral dilemmas such as the requirements of practical necessity in contrast to pointless, random acts of brutality demand more than a mere acceptance of what is comprehensible in the cognisant world, for 'changes take place on the inside' (in Pallua, 47). Colonel Kurtz, Coppola's ostensibly brutal martinet, is a suitable case-in-point. He is the embodiment of the best and worst of man: a kind of pseudo-ditheistic demigod. His desire to bring the light of white civilisation to an impoverished people is inseparable from his inordinate pride and will-to-power.

Much has been written about Kurtz. Orson Wells, who appropriated Conrad's novella for radio in 1938, drew explicit parallels between him and Hitler: 'I'm above morality...I'm the first absolute dictator' (Moore, 214). Yet, slowly in text and on film, both Marlow and Willard have become somewhat analogous with him. Marlow (like Kurtz) is put forward 'as an exceptional and gifted human creature' and an 'emissary of light' (Larabee, 60). The extent to which he comes to relate emotionally to Kurtz is suitably surmised when he says, 'I had, even like the 
Appropriating Emotional Distress, Disturbance, and Grief in the Novel Heart of Darkness and the Film Apocalypse Now - A Brief Analysis

niggers, to invoke him - himself - his own exalted and incredible degradation' (Conrad, 2011). As such, Kurtz is both inside and outside colonial power, and colonial jurisdiction. He does, by the end of the Conrad's novella, come to embody the state of exception.

As Apocalypse Now moves mournfully towards its conclusion, the cinematography and editing figuratively shows the transformation of Captain Willard. VitoroStoraro's use of pictorial lighting creates thematically symbolic shots that reveal the psychological and spiritual bond between Willard and the target of his mission, Kurtz. Both characters are filmed, backed by the haunting non-diegetic synthesised score written by Francis and Carmine Coppola, with their faces half in and out of the shadows. The lighting dictates that the moral conflict between good and evil of each character be seen as one entity, and that if Kurtz be considered devoid of method then so too must Willard: 'What do you call it when the assassins attack the assassins?' (Millius)

Jake Horsley, in his work Blood Poets: a cinema of Savagery 1958-1999, amongst many criticisms of the film's conclusion, takes umbrage with the score. He states that the 'synthesised whines and groans and heartbeats sound more like a soundtrack for a horror film.' (18) However, in view of the terrible journey Willard has made and the dreadfulness he discovers at Kurtz' compound, the avant-garde, Stockhausen-esque soundtrack is more than apt and can be deemed a nuanced approach to genre melding: breaking with custom and convention to explore a specific issue. Notably, there is a definite sense of horror throughout the scene.

In a setting dominated by corpses and death, a catalogue of unchecked violence and reciprocal vengence, Kurtz's tribesmen ritualistically dance around a fire to the mounting rhythms of their drums prior to his death. In conjunction with this repetition, the unanimous and overwhelming malice of the tribe is called forth and then discharged against the sacrificial carabao, which acts as a precursor for what is to follow; Willard as the savage tribe and Kurtz as the sacrificial carabao. By this point, Kurtz stands as the embodiment of US imperialism and as an unintentional homage to Frankenstein's monster. Harold Bloom, in his assessment of Coppola's representation of Kurtz, surmises that he alone is 'a precise definition of horror.' (4)

As Apocalypse Now concludes, greater understanding of the film's magnificent opening, which showcases one of the most elaborate uses of lap dissolve in cinematic history, is understood in greater context. By design, Coppola's intention is to present the notion of a terrible re-occurrence throughout the film - one that deals with the notion of Kurtz and the Vietnam war as a composite horror. In this respect, the end is the beginning and viceversa; i.e., a cyclical horror, which is suitably symbolised by dual and suspended metaphors. For example, the upturned, austere, and heavily perspired face of Willard in the film's opening appears as a symbolic reference to 'hot war'. His face also doubles, however, as a symbol of psychological strain born of a world very much turned on its head.

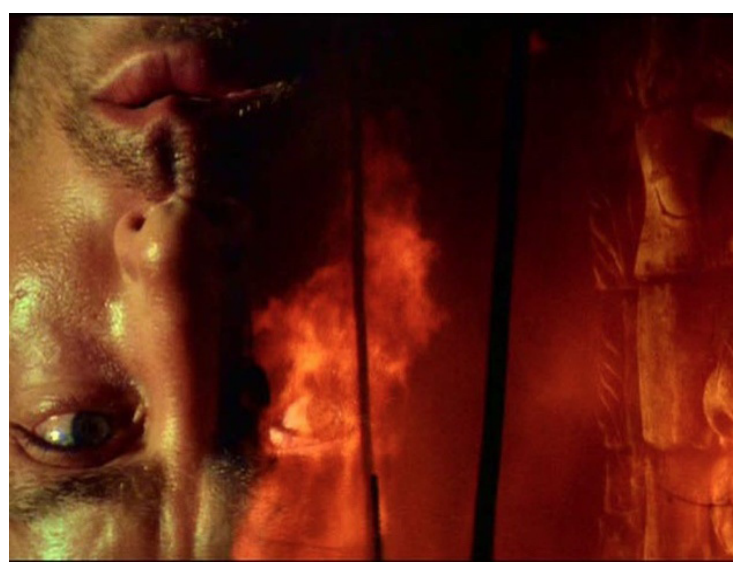

Willard's upturned head: part of Apocalypse Now's opening montage 
Appropriating Emotional Distress, Disturbance, and Grief in the Novel Heart of Darkness and the Film Apocalypse Now - A Brief Analysis

In conjunction, Coppola presents a superb dualist allegory. The rotary blades of a U.S. army helicopter are transmuted into a low-angle shot of the blades of a ceiling fan situated in Willard's Saigon hotel room. This imposition infers that the fire of the outside world and the inferno of Willard's personal distresses are fundamentally linked. This notion is reified by Willard's non-diegetic introductory voiceover, which hints that a direct route from sweat-ridden cotton sheets to dew-soaked palm trees is plausible: 'Every time I think I am going to wake back up in the jungle.' (Coppola, 1979) In this sense, Willard is in a constant state of flux:

When I was home after my first tour, it was worse. I'd wake up and there'd be nothing. I hardly said a word to my wife until I said yes to a divorce. When I was here, I wanted to be there. When I was there ... all I could think of was getting back in the jungle.

The beginnings of both works may appear on face value to have little to no coterminous characteristics, but the darkness present in Coppola's montage is also metaphorically with Marlow from the outset. In contrast to the light of ships on the London fairway, Marlow muses that 'the monstrous town was still marked ominously on the sky, a brooding gloom in sunshine.' Marlow, having returned affected by the psychological heat of the Congo, is presented as a man in possession of a heightened susceptibility to the darkness of the world, even on the placidity of the Thames. He speaks in collages of terms, referring to 'a running blaze' and the 'darkness' of yesterday; he also draws parallels between historic Roman brutality and events encountered in the Congo: '-death skulking in the air, in the water, in the bush.' Much like Willard, while at home, there is still much of Marlow that resides in the jungle.

The miserable nature of Marlow's introduction, however, invokes a curiosity in him and his story. This is similarly applicable in Apocalypse Now; a connection between protagonist and viewer is established when Willard's suffering, emotional instability, and weakness is emblazoned for all to see in the arena of his hotel room. Novella and film create a desire in their respective audiences to understand the basis of each man's torment. The sombre aura that surrounds both men can be defined as the introduction to the darkness of civilised hearts. There is a psychological intimacy at play across both works that underpins the separation of reason from civilized morality, and the fragmentation of the self so typical of the technocrat. These factors ultimately cause Marlow and Willard to favour the nightmare of Kurtz over their home lives.

While the darkness and the barbarity of man is the nucleus for both stories, questions on the sincerity of man often run parallel or underpin core themes, with emphasis placed on the notion of the lie. Marlow suitably suggests as much when he remarks that 'there is a taint of death, a flavour of morality in lies, - which is exactly what I hate and detest in the world - what I want to forget. It makes me miserable and sick, like biting something rotten would do.' (Wake, 44) These words are paralleled in Apocalypse Now when Kurtz and Willard lament the insincerity of war. Willard notes that 'it was the way we had over here of living with ourselves. We'd cut them in half with a machine gun and give them a band-aid. It was a lie. And the more I saw of them, the more I hated lies (Millius).

As the two characters chip away at the façade of deceit, their distress becomes increasingly heightened. Unlike Kurtz, in both novella and film, who has come to accept the horrors of war and in doing so displays human bodies as trophies - heads on sticks, cadavers hanging from trees and etcetera - Willard and Marlow are conflicted. In contrast, they leave their dead behind, offering them to the waters that they move on from. Neither man wants to 'make a face of horror', and yet the further they progress the deeper into the darkness they descend. Paradoxically, in doing so the torment of the past and the darkness that awaits are pieced-together in their subconscious minds to reveal an emergent kind of horror in facial form: 'the mind of man is capable of anythingbecause everything is in it, all the past as well as all the future.' (2002) 
Appropriating Emotional Distress, Disturbance, and Grief in the Novel Heart of Darkness and the Film Apocalypse Now - A Brief Analysis

It seems fitting, in this respect, that Coppola asked that Apocalypse Now be viewed not so much as an anti-war statement but as an 'anti-lie' one (Suid, 333). To return to the film's opening montage, this is symbolised aptly when an establishing shot of the Vietnamese jungle, presented in full $70 \mathrm{~mm}$ panorama, is quickly obscured by yellowish-orange napalm smoke. The tone is being established with immediate effect. The mis-en-scene insinuates calculated distortion intended to hide what the viewer sees before them. As Jinim Park asserts, 'The Vietnam War produced a postmodern space where images precede realities and where causes are distorted by effects.' (Park, 117) Thus, calculated distortion may be inferred as a reference to the general perception of America's people to the Vietnam War: what were the motives for America's presence, exactly?

This distortion is in-keeping with themes present in Heart of Darkness. For example, when Marlow embarks on the journey that will transport Kurtz from the Congo back to Europe, the natives who had worshipped him gather on the shore and open fire. As a result, Marlow remarks that he can 'see nothing for the smoke', as if the horrors of what Kurtz had nurtured and was leaving behind were being hidden. In that moment, the realisation is that Kurtz has not civilized the natives; they have savagised him; i.e., thus in novella and film, Kurtz takes on his respective surroundings, faces up to the magnitude of the lie he is a part of, and goes insane in the process.

The mental status of Willard and Marlow by the close of their respective works is somewhat uncertain, but both are deeply afflicted. This is best exemplified by Marlow, when he refers to Kurtz' soul in the process of trying to comprehend the disarray of his own conscious thoughts: 'Believe it or not, his intelligence was perfectly clear... but his soul had gone mad. Being alone in the wilderness, it had looked within itself, and, by heavens! I tell you, it had gone mad. I had-for my sins, I suppose - to go through the ordeal of looking into it myself.' A statement that can equally be applied to the Willard's perceptions of Coppola's Kurtz.

\section{CONCLUSION}

The success of novella and film as portmanteaus of emotional distress lies in their underlying messages. Whether implied or interpreted, these messages are a purposeful and poetic meditation on human existence via a confrontation with the mystery of unknown earth. In the end, it is the land that Marlow and Willard inhabit that is real, and humanity that is the nightmare. The aspects of distress, disturbance, and unhappiness that Marlow, Willard, and of course Kurtz experience are, like the tools of oppression they utilise, manmade. All three naively underestimate the power of the jungle and as they penetrate further into the heart of darkness, their capacity for 'self-control' and 'inborn strength' is tested. In conclusion, to use the words of Marlow to transcend the link between novella and film: 'I confounded the beating of the drum with the beating of my heart'. Here Marlow shows that he has reached the nucleus of his own darkness: 'the farthest point of navigation.' It is no longer with the wilderness that he grapples but the landscape of his conscience. For ultimately, one cannot serve colonialism without being corrupted by it.

\section{REFERENCES}

1. Bloom, Harold, Marlow: Major Literary Characters. Chelsea House Publishers: London, 1992.

2. Conrad, Jospeh, Heart of Darkness - Second Edition. Broadview Press: Peterborough, Canada, 1999.

3. Conrad, Joseph, Heart of Darkness and Other Tales: Oxford World's Classics. University Press: Oxford, 2011

4. Conrad, Joseph, Youth: A Narrative. CreateSpace Independent Publishing Platform: South Carolina, 2016.

5. Coppola, Eleanor, Notes. Faber \& Faber: London, 1995.

6. Coppola, Francis Ford., Apocalypse Now. DVD. Directed by Francis Ford Coppola. USA. American Zoetrope. 1979.

American Research Journal of English and Literature

Page 5 
Appropriating Emotional Distress, Disturbance, and Grief in the Novel Heart of Darkness and the Film Apocalypse Now - A Brief Analysis

7. Dobrinsky, Joseph, The Artist in Conrad's Fiction: a Psychocritical Study. UMI research Press: Michigan, 1989.

8. French, K., Karl French on Apocalypse Now: Bloomsbury Movie Guide No.1. Bloomsbury: London, 1998.

9. Hearts of Darkness: a Filmmaker's Apocalypse, 1991. Film. Directed by Fax BAHR, George Hickenlooper, Eleanor Coppola (footage). USA. American Zoetrope.

10. Horsley, J, The Blood Poets: A Cinema of Savagery1958-1999: Volume 2: Millennial Bliues-Fromthe Apocalypse Now to the Matrix. The Scarecrow Press, Inc:London, 1999.

11. Larabee, Mark D., The Historian's Heart of Darkness: Reading Conrad's Masterpiece as Social and Cultural History. ABC-CLIO: Santa Barbara, 2018).

12. Millius, Francis,'Ford Coppola, Apocalypse Now: Transcript'. Available online: http://corkyJohn.net/scripts/ apocalypsenow.html. Accessed: March 26, 2018.

13. Moore, Gene M., Conrad on Film. Cambridge University Press: Cambridge, 1997.

14. Najder, Zdzisław, Joseph Conrad: A Life. Camden House: London, 2007.

15. Park, Jinim, Narratives of the Vietnam War by Korean and American Writers. Peter LangBern: 2007.

16. Prince,S., Movies and Meaning: an Introduction to Film. Allyn and Bacon: Boston, 2001.

17. Simmons, Allan, Joseph Conrad. Macmillan International Higher Education: Basingstoke, 2006

18. Tredell, Nicholas, Joseph Conrad: Heart of Darkness. Columbia University Press: New York, 1999

19. Ulrich, Pallua, Africa's Transition from Colonisation to Independence and Decolonisation: Joseph Conrad's Heart of Darkness, Chinua Achebe's Things Fall Apart, and Moses Isegawa's Abyssinian Chronicles (IbidemVerlag: Hanover, 2004).

20. Wake,Paul, Conrad's Marlow: Narrative and Death in 'Youth', Heart of Darkness, Lord Jim andChance. Manchester University Press: Manchester, 2013).

21. Suid,L. H., Guts \& Glory: the Making of the American Military Image in Film. University Press of Kentucky: Kentucky, 2002.

Citation: Dr. Craig Doughty, "Appropriating Emotional Distress, Disturbance, and Grief in the Novel Heart of Darkness and the Film Apocalypse Now - A Brief Analysis" American Research Journal of English and Literature, vol 5, no. 1, 2019, pp. 1-6.

Copyright (c) 2019 Dr. Craig Doughty, This is an open access article distributed under the Creative Commons Attribution License, which permits unrestricted use, distribution, and reproduction in any medium, provided the original work is properly cited. 